\title{
The legacy of Alex Stacoff for foot and footwear biomechanics research
}

\author{
Peter R Cavanagh \\ From 3rd Congress of the International Foot and Ankle Biomechanics Community \\ Sydney, Australia. 11-13 April 2012
}

\begin{abstract}
Alex Stacoff was a Swiss biomechanics researcher and a key member of the small group of scientists who founded the International Foot and Ankle Biomechanics Community (i-FAB) in 2007. He was an active participant at the first i-FAB Congress in September 2008, but he died tragically while running, only three weeks later, at the young age of 58 years. The fact that a flourishing $\mathrm{i}-\mathrm{FAB}$ is now holding its $3^{\text {rd }}$ Congress in Australia is part of Alex's legacy to the field. But there are other dimensions of his legacy on both the personal and professional levels that I will explore, and hopefully extend, in my presentation. Alex's professional life was a model of perseverance from which we all can learn. He earned his $\mathrm{PhD}$ some 20 years after changing course from an intended career as a schoolteacher. Throughout this time he garnered a reputation for moderation, friendship, mentorship, generosity, and collaborative work that is a model of how research should be conducted. All this was achieved against a backdrop of personal health challenges that would have caused many lesser individuals to abandon professional activities altogether. Alex Stacoff's professional passion was to understand the biomechanics of the foot and shoe during locomotion. He used both classical and novel methods, the later including bone pin-mounted targets, magnetic resonance imaging kinematics, and fluoroscopy. He expressed an early interest in learning from barefoot running [1] and I will speculate on what he might of thought about the current obsession with this topic. He also used accelerometers attached to the body [2] and, following this lead, I will present new data from our laboratory that demonstrates how skin-mounted accelerometers provide reliable and insightful signals to understand bilateral
\end{abstract}

Correspondence: cavanagh@uw.edu

Department of Orthopaedics and Sports Medicine, University of Washington, Seattle, WA 98195107, USA and intra-subject differences in the foot strike patterns of women distance runners.

Published: 10 April 2012

\section{References}

1. Stacoff A, Nigg BM, Reinschmidt C, Van Den Bogert AJ, Lundberg A: Tibiocalcaneal kinematics of barefoot versus shod running. J Biomech 2000, 33:1387-95.

2. Maffiuletti NA, Gorelick M, Kramers-de Quervain I, Bizzini M, Munzinger JP, Tomasetti S, Stacoff A: Concurrent validity and intrasession reliability of the IDEEA accelerometry system for the quantification of spatiotemporal gait parameters. Gait Posture 2008, 27:160-163.

doi:10.1186/1757-1146-5-S1-K2

Cite this article as: Cavanagh: The legacy of Alex Stacoff for foot and footwear biomechanics research. Journal of Foot and Ankle Research 2012 5(Suppl 1):K2.
Submit your next manuscript to BioMed Central and take full advantage of:

- Convenient online submission

- Thorough peer review

- No space constraints or color figure charges

- Immediate publication on acceptance

- Inclusion in PubMed, CAS, Scopus and Google Scholar

- Research which is freely available for redistribution

Submit your manuscript at www.biomedcentral.com/submit
() Biomed Central
C Biomed Central

ㄷ 2012 Cavanagh; licensee BioMed Central Ltd. This is an Open Access article distributed under the terms of the Creative Commons Attribution License (http://creativecommons.org/licenses/by/2.0), which permits unrestricted use, distribution, and reproduction in any medium, provided the original work is properly cited. 